\title{
Investigation Into The General Acceptance Of AACSB Ethics Standards
}

Mark Myring, (Email: mmyring@bsu.edu), Ball State University William Wrege, (Email: wwrege@bsu.edu), Ball State University

\begin{abstract}
The Association to Advance Collegiate Schools of Business (AACSB) has long required the integration of ethics into the accounting curriculum of accredited schools. Little research investigates how this requirement is implemented. We conduct a survey of accredited and nonaccredited institutions to determine how ethics are integrated into the accounting curriculum. Results of this survey are of interest to individuals at accredited and non-accredited schools.
\end{abstract}

\section{INTRODUCTION}

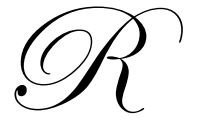

ecent well publicized accounting scandals have called into question the ethics of accountants and businesspeople in general. As a result of these scandals, new laws and regulations have been put into place to reduce the probably and/or increase the detection of unethical behavior. Regardless of the controls and regulations in place, unethical behavior is likely to occur.

Many believe that the integration of ethics into accounting curricula will decrease the probably of unethical behavior among accounting graduates. To this end, the Association to Advance Collegiate Schools of Business (AACSB) requires the integration of ethics into accounting curricula. "Campaign AACSB" is an effort to improve ethics accreditation standards in US Business Schools. A number of business professors and former deans have criticized the AACSB standards on ethics, or lack thereof, arguing that the flexible criteria can only serve to contribute to corporate corruption. This campaign has called for a required, standalone ethics course at each business school, rather than just having ethics embedded or sprinkled (Swanson and Fredrick 2003). In addition, the National Association of State Boards of Accountancy (NASBA) has recently proposed new requirements for the integration of ethics into accounting curricula. Despite repeated calls for integration of ethics into accounting curricula, no research has investigated how and if universities are integrating ethics.

In this study, we surveyed accounting programs in the U.S. to determine the extent of integration of ethics into accounting curricula. In addition, we investigated the techniques used to integrate ethics. Finally, we investigated differences in the integration of ethics across AACSB accredited schools and those that are not accredited by the AACSB. We are reporting the results of the pilot data gathered.

\section{IMPETUS AND OBJECTIVES FOR THE STUDY}

The Association to Advance Collegiate Schools of Business (AACSB) promulgates standards of practice and achievement for colleges/schools of business that desire accreditation from the AACSB. The AACSB believes its International accreditation represents the highest standard of achievement for business schools, worldwide; and that institutions that earn accreditation demonstrate to their stakeholders a high level of excellence in management education. Specifically, accreditation by the AACSB assures stakeholders that business schools:

- $\quad$ Manage resources to achieve a vibrant and relevant mission.

- $\quad$ Advance business and management knowledge through faculty scholarship.

- $\quad$ Provide high-caliber teaching of quality and current curricula.

- Cultivate meaningful interaction between students and a qualified faculty.

- $\quad$ Produce graduates who have achieved specified learning goals. 
The standards include pedigree criteria, such as course coverage by people with terminal degrees in their major area. They also include standards for ongoing faculty development to maintain qualifications, such as demonstration of continuing research/publishing by the faculty. Some of the standards, however, are not essentially discipline or technically based. They are part of AACSB standards, however, and are areas of policy and practice development and compliance that are examined and presumably considered during an accreditation examination. These areas include diversity, ethics, discipline integration, group dynamics, and communication skills. They stem from the objective of the accreditation process, which is to assist management education programs to meet complex demands on management and accounting education. The AACSB identifies the challenges to those programs, which mirror the challenges to organizations and managers, as:

- $\quad$ Strong and growing global economic forces.

- $\quad$ Differences in organizational and cultural values.

- Cultural diversity among employees and customers.

- $\quad$ Changing technology in products and processes. (AACSB, p.1)

We wish to determine if the requirements outside the discipline based requirements are perceived as important attributes of a business program integral to imparting quality education which prepares students "...to contribute to their organizations, the larger society, and to grow personally and professionally throughout their careers." (AACSB p.1) The objective of this paper is to assess the general acceptance of one aspect of non-discipline based AACSB standards, ethics, among accounting department chairs/heads and to investigate compliance with those standards.

\section{EXISTING LITERATURE ON THE GENERAL ACCEPTANCE OF AACSB ETHICS STANDARDS}

Previous research has investigated the impact of AACSB standards on accounting and business curricula. For example Conover et al. (1994) and Sands and Pragasam (1997) find evidence of integration of international topics into accounting curricula (a requirement of AACSB standards). However, very little research investigates the integration of published articles on general AACSB standards pertaining to ethics, diversity, and globalization, let alone their general acceptance.

Miles, Hazeldine, and Munilla (2004) examine the thrust of AACSB accreditation standards, how they differ from prior AACSB standards, and the implication of the new standards for faculty at business schools. The authors observe that (p.30): "Accreditation is a hallmark of quality and provides students and other business-school stakeholders with an objective, third-party assurance that the business school is conforming to sound, academic management practices and a somewhat accepted curricula. ..”.

Ward and Dugger (2002), compare selected standards of the NAIT (i.e., National Association of Industrial Technology), TAC-ABET (i.e.,) and AACSB. The authors list such standards comparatively, in three columns. The other two accreditation agencies have nothing whatsoever to match the AACSB standards on (p.4): "Ethical and global issues; influence of political, social, legal, and regulatory environmental \& technological issues; impact of demographic diversity on organizations". Nonetheless ABET includes, among a list of factors to assess faculty competence and effectiveness (p.6), "diversity of background" and "exemplary ethical and professional behavior."

Bicker examines how one business school implemented AACSB standards on intellectual contributions, even though the school was traditionally teaching-oriented. The school used a mentoring program linking non-research with research faculty. There was concern among faculty that the AACSB standards applied to this business school would be more stringent than those for the university as a whole. Therefore, special funding for faculty research was provided in this school. The school found that the entire faculty should be involved in the process of implementing the accreditation standards. 


\section{Survey And Data Collection}

Data was collected for this study by e-mailing invitations to accounting department chairs/heads of accounting programs obtained from the 2005 edition of the Hasselback Accounting Faculty Directory. The e-mail requested their participation in an on-line survey regarding accounting ethics. The e-mail contained a link to the survey.

The survey consisted of a series of questions designed to ascertain both the chair's perception of the importance of the integration of ethics in the accounting curricula and the extent to which the department has integrated ethics into the curricula. In addition, the survey questions were designed to ascertain the methods of and support for the integration of ethics into the curricula. A copy of the survey is included in the appendix of this paper.

\section{PILOT RESULTS AND CONCLUSION}

This paper reports the results of a pilot study using the survey data. Thus, the results of this study are very preliminary and may not be representative of the underlying population. The majority of respondents where from pubic universities with relatively small accounting programs (less then 50 students). Most of the sample universities offered some sort of graduate program in the college of business. Finally, the majority was AACSB accredited at the college level; about half were accredited at the department level.

Our analysis leads us to believe that the primary pressure to integrate ethics into to curriculum comes from the AACSB, followed by pressure from employers. Results of the survey suggest that though ethics is perceived to be an important topic. Despite the pressure to integrate ethics and its perceived importance, no surveyed institutions offer incentives (e.g., teaching load reductions, financial) to integrate ethics into the accounting curricula. The majority of colleges do require accounting students to take a stand alone ethics course. Also, ethics often is integrated into individual accounting courses. The most common methods used to integrate ethics within courses are information provided in textbooks, real world examples and cases. The most common obstacles to integration of ethics are the overcrowded accounting curricula and lack of faculty interest.

We look forward to analyzing the full survey results to determine whether the pilot study results are confirmed or disconfirmed. We wonder if the universal response that ethics is an important topic stems from actual belief or from a sort of peer pressure. We found dis-consonance between the dramatic agreement with the notion that ethics is important and the spare actions to implement ethics instruction in accounting curricula. Until actions on the part of school/faculty match the asserted belief that ethics is paramount to the delivery of quality business education, then we doubt that people really believe ethics instruction is possible or important.

\section{REFERENCES}

1. Becker, R. F. Developing AACSB Mission-Linked Intellectual Contributions Standards Within Institutions that Have Historically Focused on Teaching. www.nssa.us/nssajrnl/23 1/htm/01.htm.

2. Conover, T., S. Salter, and J. Price. 1994. International accounting education: A comparison of course syllabi and CFO preferences. Issues in Accounting Education 9(2): 259-271.

3. Miles, M. P., M. F. Hazeldine, and L. S. Munilla. The 2003 AACSB Accreditation Standards and Implications for Business Faculty: A Short Note. Journal of Education for Business. September/October, 2004.

4. Sands, J. and J. Pragasam. 1997. The perceived importance of international accounting topics in the AsiaPacific rim: A comparative study. International Journal of Accounting 32(2): 187-203.

5. Swanson, D. and W. C. Frederick, Campaign AACSB: Are Business Schools Complicit in Corporate Corruption? Journal of Individual Employment Rights, March 2003.

6. Ward, C. D. and J. Dugger. A Comparison of Selected Categories of Accreditation Standards of NAIT, TECABET, and AACSB. Journal of Industrial Technology, Vol. 18, No. 3, May 2002 to July 2000. 


\section{APPENDIX: SURVEY}

\section{Indicate your level of agreement on the 5-point rating scale:}

1. Ethical behavior on the part of faculty and students is paramount to the delivery of quality business education. Strongly disagree

$$
1
$$

2

$\begin{array}{lll}3 & 4 & 5\end{array}$

2. School codes of conduct are important to defining proper behavior for faculty and students.

Strongly disagree

$\begin{array}{llll}1 & 2 & 3 & 4\end{array}$

3. Ethical behavior cannot be taught effectively in business schools.

Strongly disagree

Strongly agree

$\begin{array}{lllll}1 & 2 & 3 & 4 & 5\end{array}$

4. Enforcement of codes of conduct with punishment for infractions is more important to teaching ethical behavior than formal instruction on ethical behavior.

\begin{tabular}{ccccc} 
Strongly disagree & & \multicolumn{2}{c}{ Strongly agree } \\
1 & 2 & 3 & 4 & 5
\end{tabular}

5. Classroom instruction regarding ethical behavior is important.
Strongly disagree
12
$\begin{array}{llll}2 & 3 & 4 & 5\end{array}$

6. Does your college/school of business offer a course which is predominantly a course in ethics? YES NO

If no, are ethics issues integrated into the following courses (if they are integrated, please indicate the manner)?

YES NO

\begin{tabular}{|l|l|l|l|l|l|}
\hline & Cases & $\begin{array}{c}\text { Academic } \\
\text { Readings }\end{array}$ & $\begin{array}{c}\text { Real-world } \\
\text { examples (a) }\end{array}$ & Not integrated & Other \\
\hline $\begin{array}{l}\text { Introductory } \\
\text { accounting }\end{array}$ & & & & & \\
\hline $\begin{array}{l}\text { Intermediate } \\
\text { accounting }\end{array}$ & & & & & \\
\hline $\begin{array}{l}\text { Gov. \& Nonprofit } \\
\text { accounting }\end{array}$ & & & & & \\
\hline $\begin{array}{l}\text { Tax } \\
\text { accounting }\end{array}$ & & & & & \\
\hline Auditing & & & & & \\
\hline Systems & & & & & \\
\hline $\begin{array}{l}\text { If you answered } \\
\text { "Other" please } \\
\text { cite an example }\end{array}$ & & & & & \\
\hline
\end{tabular}

(a) e.g., from newspapers. 
7. Does your school/college offer incentives to faculty to integrate ethics coverage in courses?

Yes No

If yes, do they include:

Financial incentives

Teaching load reductions

Research funds

Funds to attend conferences

Promotion and tenure consideration

$\begin{array}{cc}\text { Yes } & \text { No } \\ \text { Yes } & \text { No } \\ \text { Yes } & \text { No } \\ \text { Yes } & \text { No } \\ \text { Yes } & \text { No }\end{array}$

8. Rate possible incentives to your department to assure ethics coverage through the accounting and/or business curricula (either through a stand alone course or as part of discipline based courses).

It is part of the department's mission statement

Not important Very important

$\begin{array}{lllll}1 & 2 & 3 & 4 & 5\end{array}$

There is pressure from the school administration

Not important

Very important

$\begin{array}{lllll}1 & 2 & 3 & 4 & 5\end{array}$

There is pressure from recruiters/employers of graduates

Not important

Very important

$\begin{array}{lllll}1 & 2 & 3 & 4 & 5\end{array}$

They are part of accreditation requirements

Not important

$\begin{array}{lllll}1 & 2 & 3 & 4 & 5\end{array}$

Other (please specify)

9. Rate the obstacles to your department to assure ethics coverage through the accounting and/or business curricula (either through a stand alone course or as part of discipline based courses).

Insufficient funds

Not important

Very important

1

2

3

$4 \quad 5$

Insufficient student interest

Not important

1

23

Very important

Insufficient faculty interest

Not important

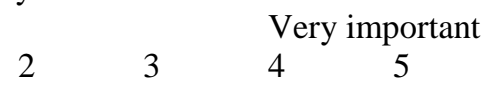

Insufficient market demand from recruiters/employers of graduates

Not important

Very important

$\begin{array}{lllll}1 & 2 & 3 & 4 & 5\end{array}$

Lack of faculty expertise

Not important

$\begin{array}{lllc} & & \text { Very important } \\ 2 & 3 & 4 & 5\end{array}$


Overcrowded curricula

Not important Very important

$\begin{array}{lllll}1 & 2 & 3 & 4 & 5\end{array}$

10. Integration of ethics coverage into the accounting curricula is easier today than in the past because of:

Greater awareness of ethics issues because of highly publicized accounting scandals

Strongly disagree Strongly agree

$\begin{array}{lllll}1 & 2 & 3 & 4 & 5\end{array}$

Greater availability of good teaching resource materials (cases, articles, inclusion in accounting textbooks) Strongly disagree

$\begin{array}{lllll}1 & 2 & 3 & 4 & 5\end{array}$

Improved accounting faculty expertise in teaching business ethics.

Strongly disagree

Strongly agree

$\begin{array}{lllll}1 & 2 & 3 & 4 & 5\end{array}$

\section{Demographic question:}

Please complete the following demographic questions:

1. Is your university/college public or private?

2. What is the enrollment of your institution?

- $\quad$ Fewer than 10,000 students

- 10,000 to 20,000 students

- $\quad$ Over 20,000 students

3. Is your school/college AACSB accredited?

4. Is your accounting program AACSB accredited?

5. Does your Business school/college offer a doctoral level degree with a major in accounting? Approximate enrollment

6. Does your Business school/college offer a masters level degree such as MS-Accounting or MBA? Approximate enrollment

7. Does your Business school/college offer an undergraduate level degree in accounting? Approximate enrollment

8. How many years have you been department chair/head?

$\begin{array}{ll}- & 1-3 \\ \text { - } & 3-6 \\ & \text { more than } 6 \text { years }\end{array}$

9. What is your American Accounting Association region?

10. How many times have you been a member of an AACSB visitation team examining another school? 